\title{
MICRO CONTROLLER AND COMPUTER BASED REACTIVE POWER COMPENSATION
}

\author{
Ercan Nurcan Yilmaz, Olcay Aydin
}

Original scientific paper Reactive power compensation methods are one of the most effective methods to improve the efficiency of energy systems. Therefore, the designs and implementations of these systems are important. The aim of this study is to design and implement the most appropriate reactive power compensation systems in electrical power systems. Reactive power compensation can be realized using capacitors or the synchronous motors. In this study, a microcontroller and computer-controlled compensation applications are done by capacitors and synchronous motors under the same load conditions has been performed. By means of this designed system, it has been tried to determine what type of reactive power compensation is suitable in the existing system. In this respect, it is aimed to avoid unnecessary investments for existing systems and to establish a quality compensation system. In addition, the designed system is easy to update against all kinds of load changes and does not require additional equipment.

Keywords: C \#; PIC (peripheral interface controller); reactive power compensation

\section{Kompenzacija jalove snage zasnovana na mikro regulatoru i računalu}

Izvorni znanstveni članak Metode za kompenzaciju jalove snage su među najučinkovitijim metodama za povećanje učinkovitosti energetskih sustava. Stoga su projektiranje i primjene tih sustava vrlo važni. Cilj ovog istraživanje je projektirati i primijeniti sustave za kompenzaciju jalove snage koji najviše odgovaraju elektroenergetskim sustavima. Kompenzacija jalove snage može se realizirati primjenom električnih kompenzatora ili sinkronih motora. U ovom radu, kompenzacije pomoću mikroregulatora i računala izvršene su primjenom električnih kompenzatora i sinkronih motora pod istim uvjetima opterećenja. Pomoću takvog sustava pokušalo se odrediti koja je vrsta kompenzacije jalove snage pogodna u postojećem sustavu. U tu su se svrhu pokušala izbjeći nepotrebna ulaganja u postojeći sustav i stvoriti kvalitetan kompenzacijski sustav. Uz to, projektirani se sustav može lako prilagoditi svim vrstama promjena opterećenja te ne zahtijeva dodatnu opremu.

Ključne riječi: C \#; kompenzacija jalove snage; PIC (regulator perifernog sučelja)

\section{Introduction}

Due to rapid population growth, industrialization and technological developments, the need for electricity has steadily increased and the world has come to the brink of the energy crisis. With this energy crisis, researchers are looking for new energy sources. But, finding a new energy source is difficult and expensive. Therefore, it is more appropriate to focus on energy-saving work. Due to the efficient use of energy, the decrease in energy consumption will lead to a decrease in energy production investments and energy costs. This is also very important in terms of reducing environmental problems $[1,2]$.

To increase the efficiency of energy systems and one of the most effective ways to save energy is reactive power compensation [3]. Reactive power compensation systems can basically be divided into static and dynamic systems.

In the static phase shifter using a capacitor made of reactive power compensation system to provide the required reactive power compensation is accomplished by gradually switching capacitor or capacitors of various groups $[4,5]$.

Dynamic reactive power compensation system in the phase shifter using a synchronous motor is made by adjusting the excitation current applied to the motor windings of the motor by running as inductive or capacitive $[6,7]$.

When the literature is examined, it is seen that there are many microprocessor based designs that use these two systems together $[8 \div 10]$.

In this study, both static and dynamic phase shifting is performed in the compensation applications and computer-based microcontroller. Capacitor groups are used as static phase shifter. The switching of the capacitor groups is done both manually and automatically. The synchronous motor is used as dynamic phase shifter. The excitation current of the used synchronous motor is automatically adjusted both in manual and artificial neural network control. Software has been developed to better understand system results and ensure correct operation. Using the computer interface created with C \# software language, the values of the system were monitored and control processing was performed in the compensation application. In addition, the performances of the applications performed were tested and compared repeatedly under different load conditions.

\section{Reactive power compensation}

The magnetizing current, which is necessary for the operation of electrical devices such as generators, transformers, coils and motors, which works according to the electrodynamics principle, is called reactive current and hence it is called reactive power. In addition to the active power that is useful for these magnetic field devices, there is a need for reactive power. The reactive current is not translated into useful power and power plants, generators, transformers, lines, coils cause heat loss and voltage drop by installing unnecessarily.

Even by increasing the generator excitation generator will be able to produce reactive power. In this way the plant produced reactive power generator, transformer, and transmitted over the power transmission line through to the consumer. But in the meantime they will be occupied unnecessarily by power plants reactive power, active power cannot be exploited fully in terms of capacity and operation uneconomic. So the reactive power production 
plants also are not more appropriate to produce the consumption point [10].

Benefited from two business tools for reactive power generation are: Capacitors (static phase shifters) and the other synchronous motors (dynamic phase shifters).

Reactive power in the compensation with capacitors is met by the capacitors in terms of their capacities. Capacitor connected in series with transmission line reduces the effective reactance of line, thus affecting the improvement of voltage circumstances on the line. In many cases, compensation with serial capacitor on transmission lines proved to be a more economical solution than building new transmission lines, and so the temporary or permanent suspension of construction of new lines is enabled [11]. Reactive power compensation is met at the border and in synchronous motors can be replaced with the synchronous motor excitation current. The cause of this is probably the high modeling complexity and problem programming because it is difficult to determine the limits of the excitation current regulation due to variable loads [12].

\section{Design of reactive power compensation system}

System in this study can be divided into two main sections, measurement and control.

Measuring section is composed of the following parts:

- LV25P voltage sensor voltage reading module for voltage reference signal (Fig. 1)

- LA55P current sensor current reading module for the current reference signal (Fig. 2)
- LM358 integrated zero crossing module for power factor and frequency reference signal (Fig. 3)

- The implementation of the reference signal received from the module, the realization of the measurement process and the measurement results to a $\mathrm{PC}$ using the USB module microcontroller module

- To supply voltage of the module, power module

- Computer interface measurement section (Fig. 4)

- The control module is composed of the following parts.

- Control module for controlling the compensation capacitor (Fig. 5)

- Excitation current sources of compensation with synchronous motor drive smart device (Fig. 6)

- PWM-controlled power supply module for the current setting of the Smart drive device

- The feed module, for supply voltage of the module

- Control process by providing appropriate output microcontroller module (Fig. 7)

- Computer interface control section 1, 2 (Fig. 4).

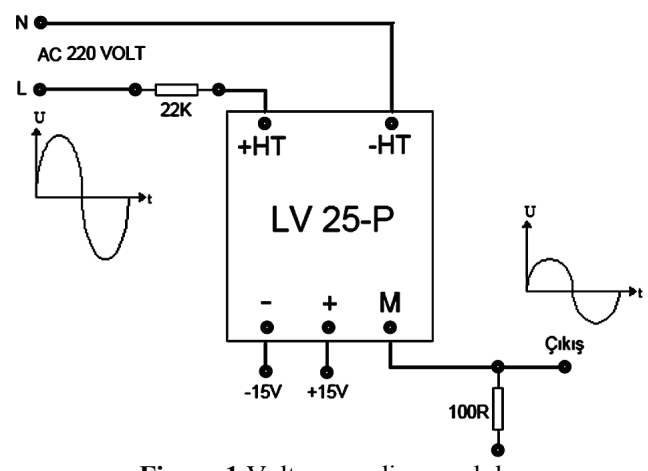

Figure 1 Voltage reading module

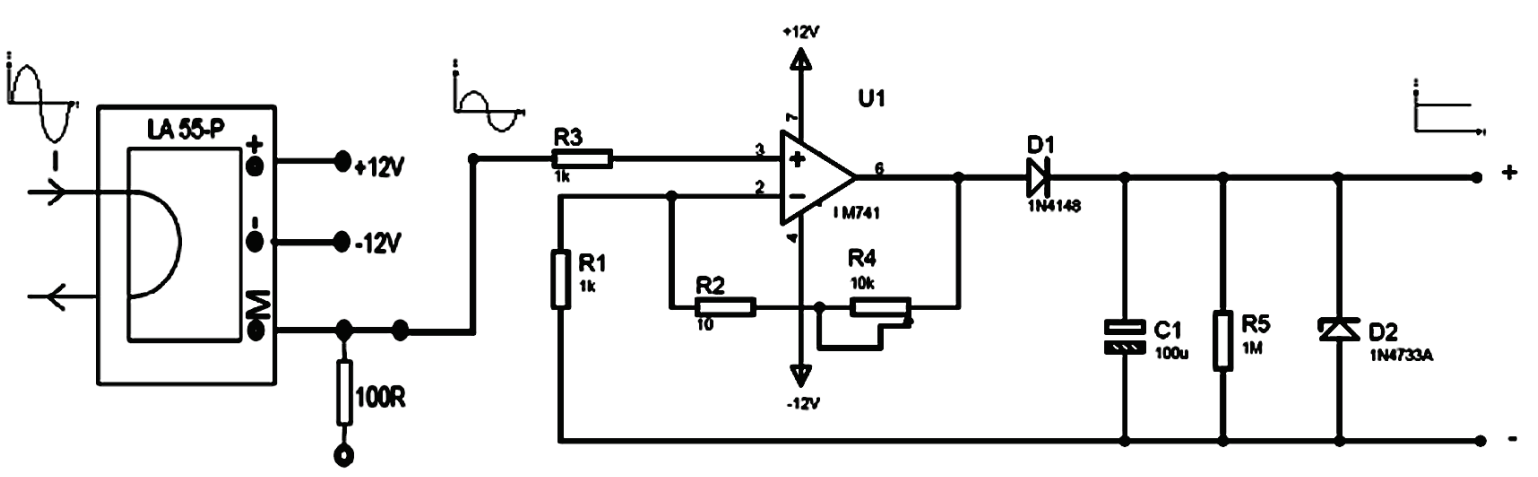

Figure 2 Current reading module

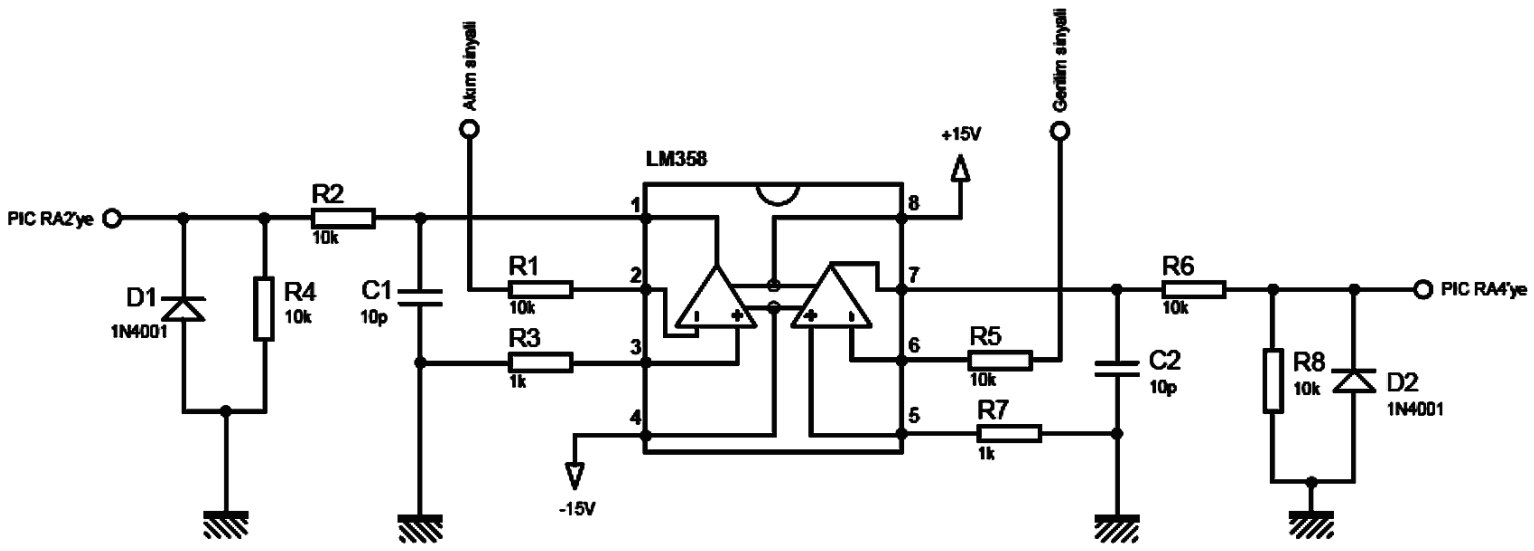

Figure 3 The zero crossing detector 


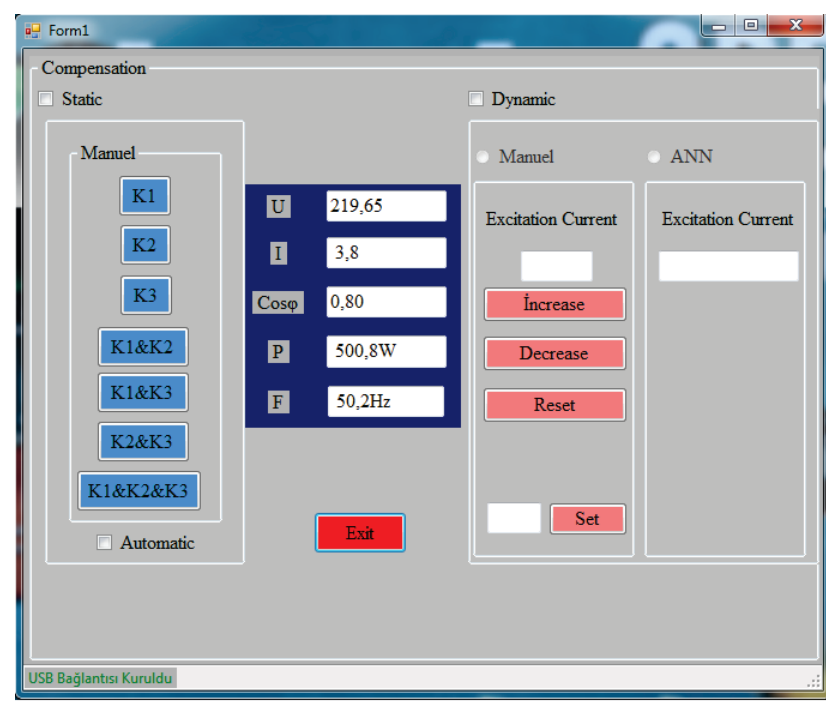

Figure 4 The computer interface
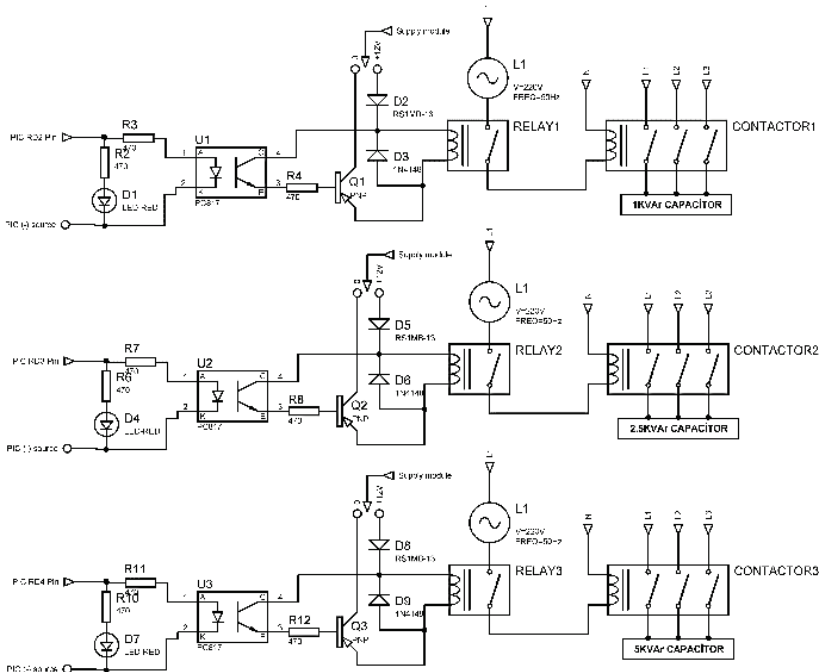

Figure 5 Control module

In this study, microcontroller module is the brain of the system location. As a microcontroller, manufactured by the company Microchip PIC 18F4550 microcontroller is used. This causes the microcontroller to use model equipped with a USB module. This module is provided through communication with the computer via the USB port.

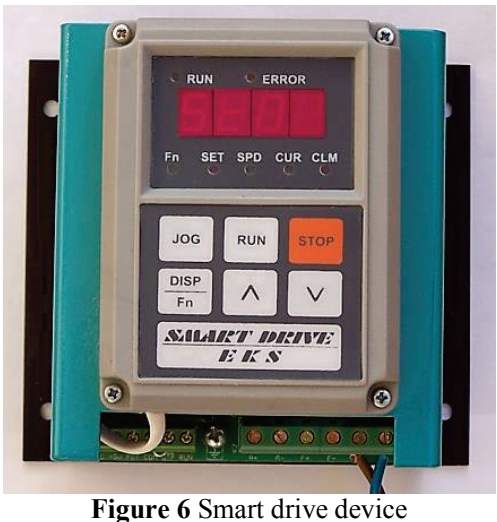

The designed system measuring and control section is shown in Fig. 7, the general block diagram in Fig. 8.

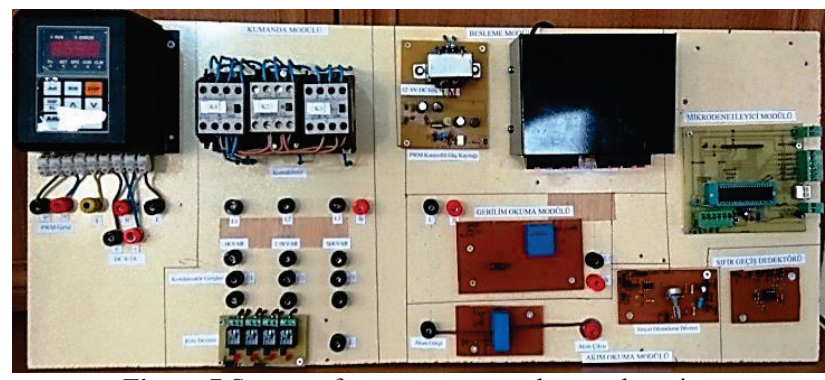

Figure 7 System of measurement and control section
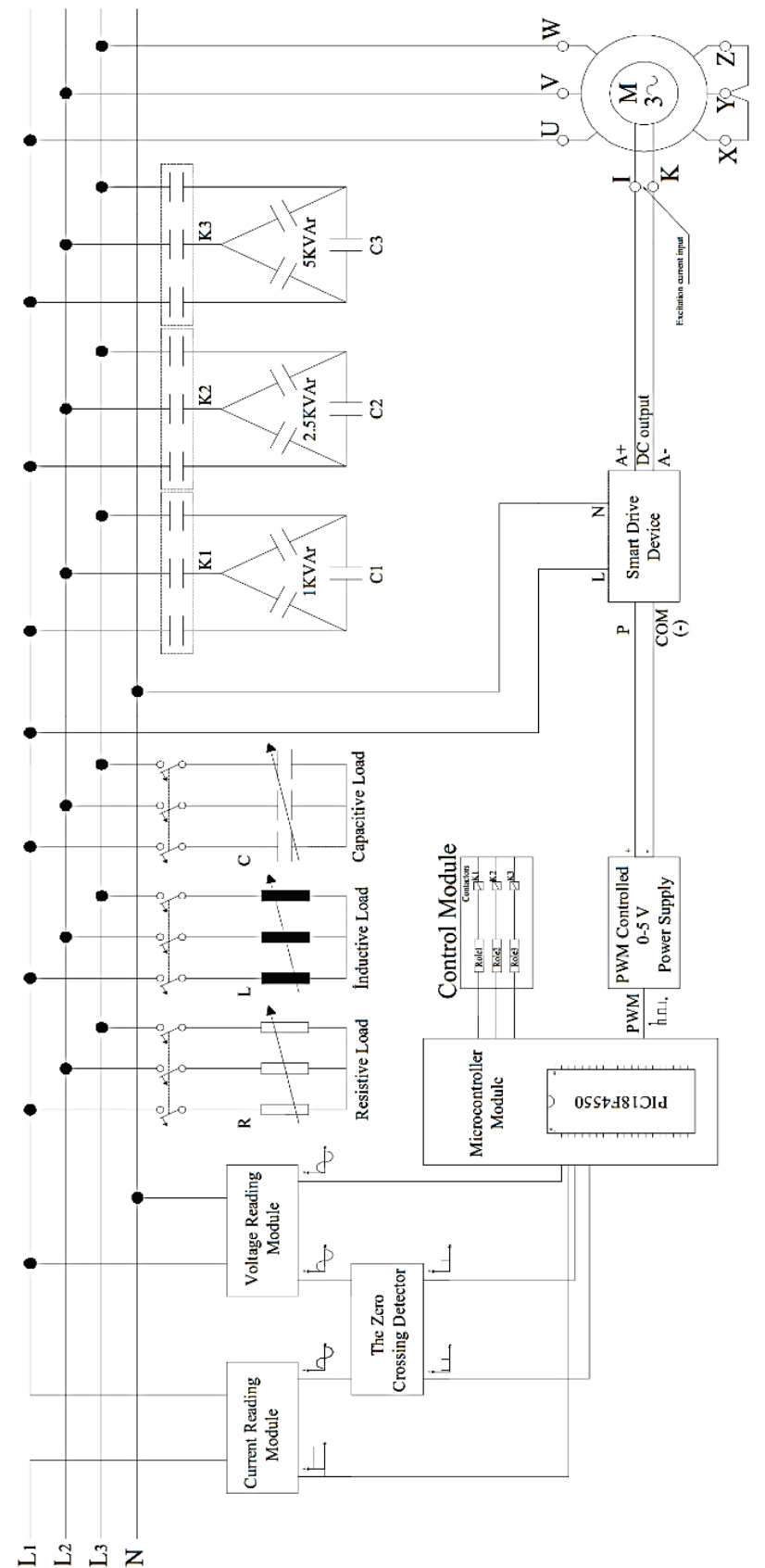

Figure 8 The block diagram of the system

\section{Results of application and analysis}

In this study, compensation system was implemented by using a capacitor as a static phase shifter and a synchronous motor as a dynamic phase shifter in the designed system. These applications are repeated according to dynamic and static phase shifters under 
different load conditions. Both manual and automatic control methods are used for compensation applications made with capacitor and synchronous motor. Two different methods are used in the automatic control. These methods are based on switching the capacitor with reactive power values at specified intervals, depending on the measurement. The second is that the excitation current of the synchronous motor is estimated and applied by the generated ANN model. Three switches have been used for compensating with the capacitor. $\mathrm{K} 1$ contactor switches 1 kVAR, K2 contactor 2,5 kVAR, K3 contactor switches 5 kVAR capacitor.

In the applications, the system of measurements was made separately with the oscilloscope and the designed circuit. As to the monitoring and recording of these measurements, an interface has been made simultaneously with the computer program. In measurements with oscilloscope, oscilloscope's "A" of the channel signal output voltage zero crossing detector, the "B" channel is connected to the output of the zero crossing detector current signal.

In exemplary applications, the interface with the monitored voltage, current waveforms and voltage of the system $(U)$, current $(I)$, power factor $\left(p_{\mathrm{f}}\right)$, the active power $(P)$ and frequency $(F)$ are located in the measurement result.

$424 \Omega$ resistive and $700 \mathrm{mh}$ inductive loads loaded application in the system.

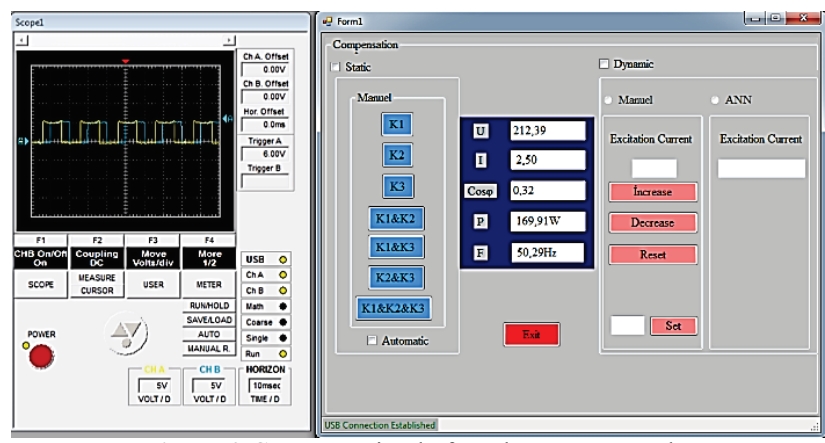

Figure 9 Compensation before the system results

Pre-compensation, power factor $\left(p_{\mathrm{f}}\right)$ value of 0,32 showed the system's inductive character. These measurement results of the system are given in Fig. 7.

The measurement results are analyzed in Fig. 7, there is a need for compensation system for reactive power needs.

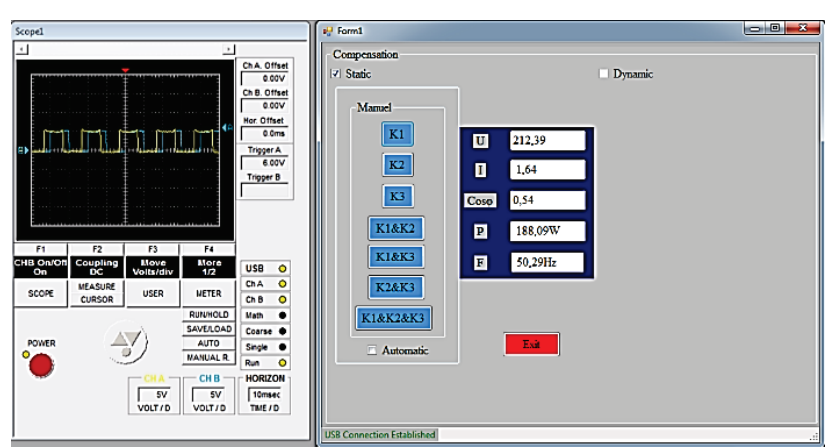

Figure 10 Measurement results after capacitor compensation (1 kVAR)

After compensation performed with the capacitor, the system of measurement results is given: manually controlled compensation in Fig. 9, automatic control compensation in Fig. 10.

When examining Fig. 10, if the synchronous motor excitation current is set to 1,4 , and it reached 0,97 the excitation current value of the power factor is sufficient in this load conditions.

As shown in Fig. 11, for application to the synchronous motor by ANN excitation current actual value of the missing 0,1 is estimated. Power factor value at this moment is still 0,97 and 2,7 to the excitation current is sufficient for these load conditions.

Under these application conditions, the compensation of the $1 \mathrm{kVAR}$ capacitor is insufficient. On the 2,5 kVAR capacitor, as shown in Fig. 10, it became excessive and the system showed capacitive character. In this experiment, since the intended $\cos \varphi$ value cannot be reached in compensation, the capacitor capacities in the system are insufficient. As a result, the capacitor power to be selected under these load conditions must be between 1 $\mathrm{kVAR}$ and 2,5 kVAR.
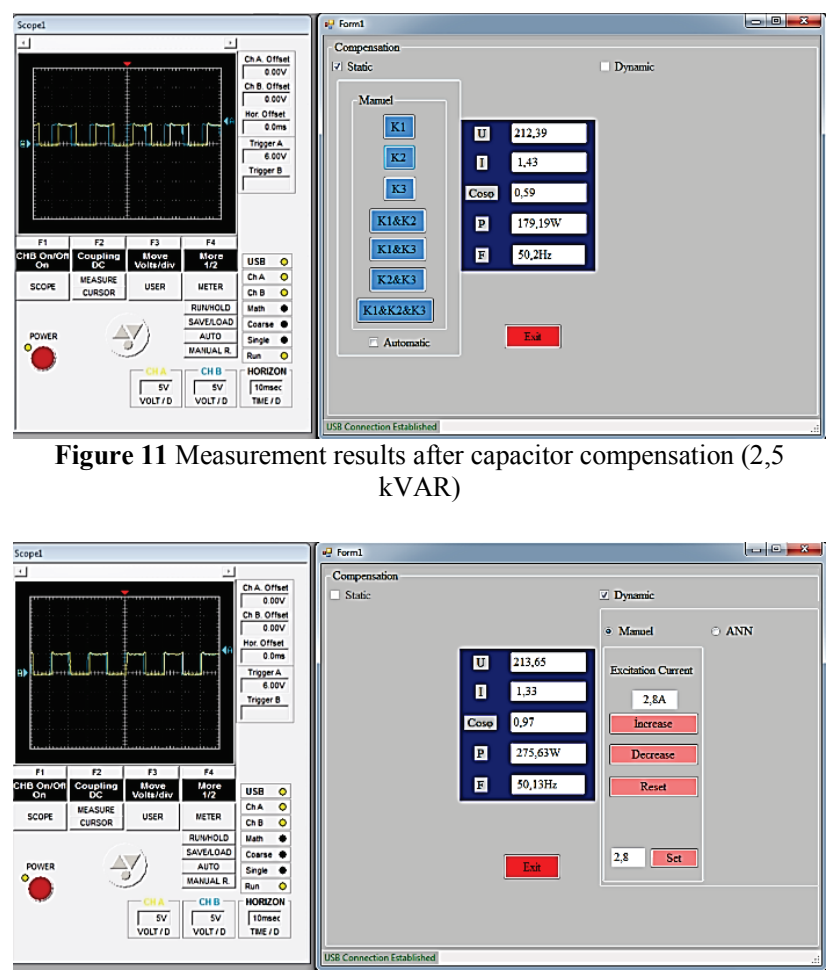

Figure 12 Measurement results after compensation with manual controlled synchronous motor

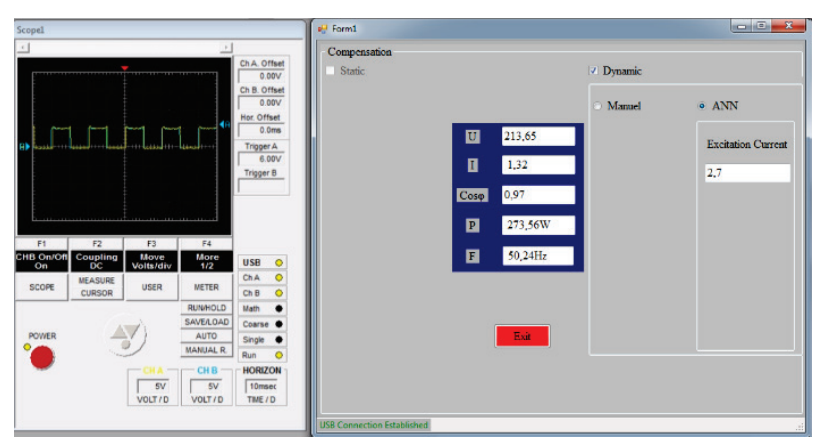

Figure 13 The values measured after compensation with ANN supervised automatic control synchronous motor

Fig. 12 shows the measurement results of the system after compensation with the manual controlled 
synchronous motor and Fig. 13 shows the automatic controlled compensation with YSA supervision.

Capacitors and compensation applications with synchronous motor are built with both manual and automatic control methods in the same load conditions and a total of 4 separate applications have been made. Fig. 14 depicts a set of experiments showing the application.

The example given in the application and other related experiments show manual control method applied to determine the value to be used in the creation of the automatic control system. Automatic control methods, in particular, are preferred in the control of the compensation system designed for the consumer.

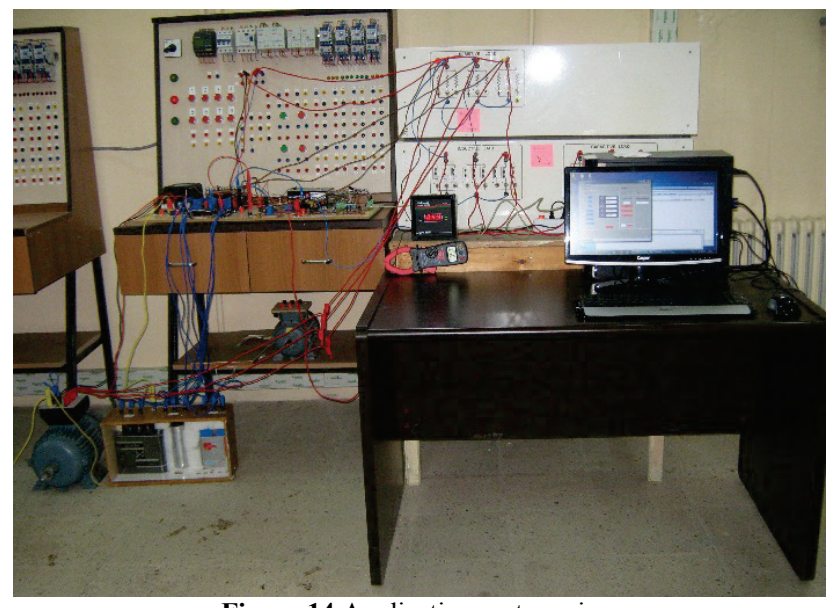

Figure 14 Application system view
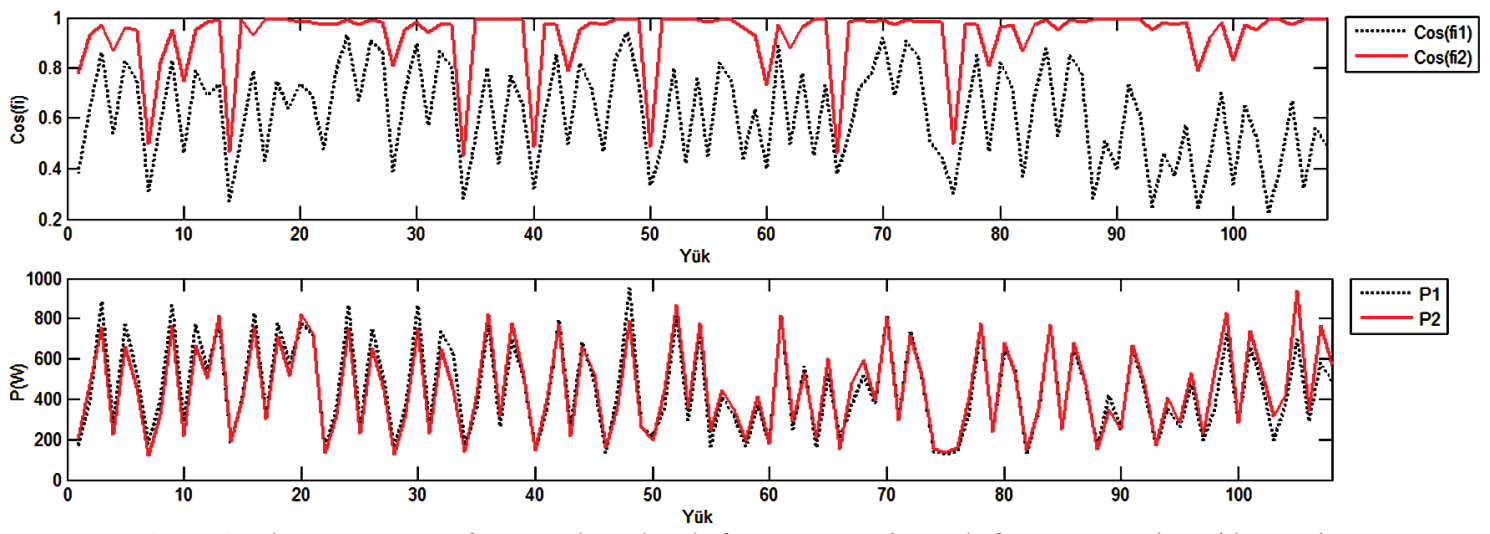

Figure 15 The system power factor, and $P$ values before compensation and after compensation with capacitor
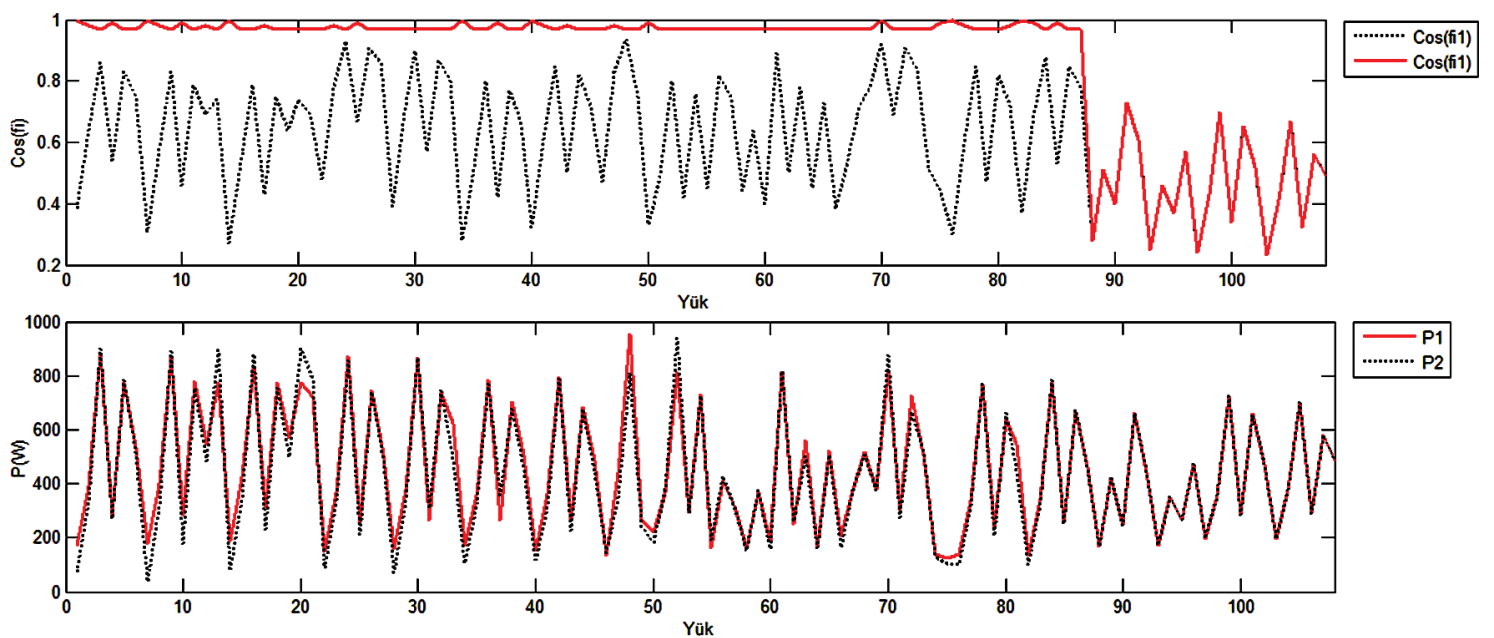

Figure 16 The system power factor, and $P$ values before compensation and after compensation with synchronous motor
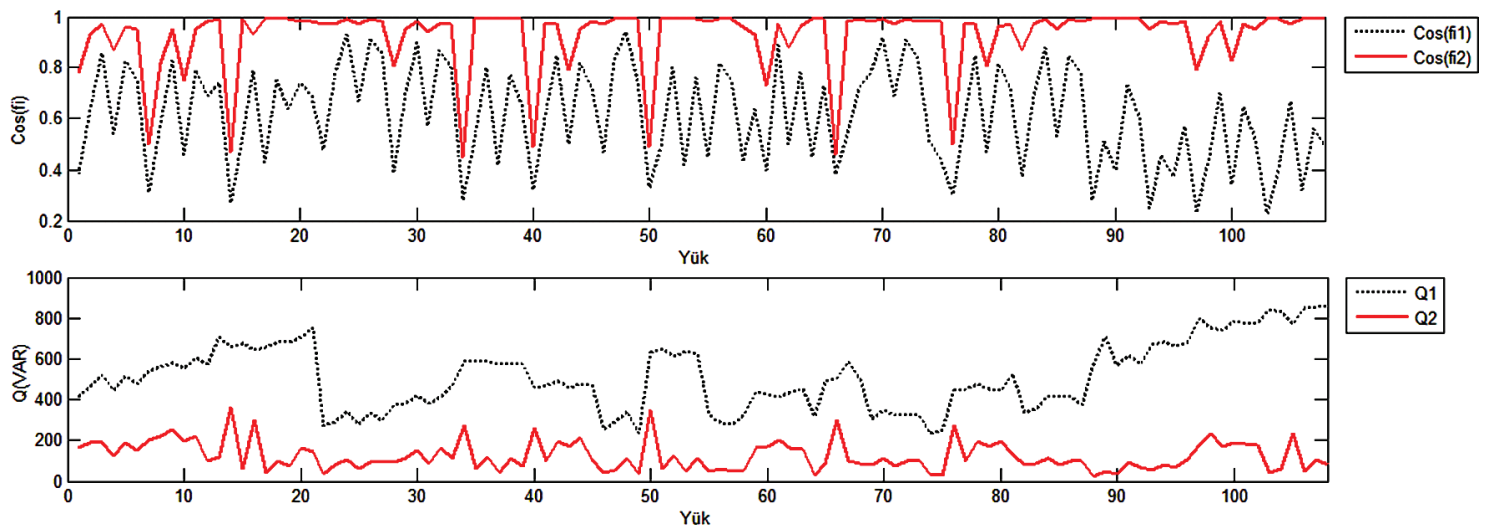

Figure 17 The system power factor and $Q$ values before compensation and after compensation with capacitor 

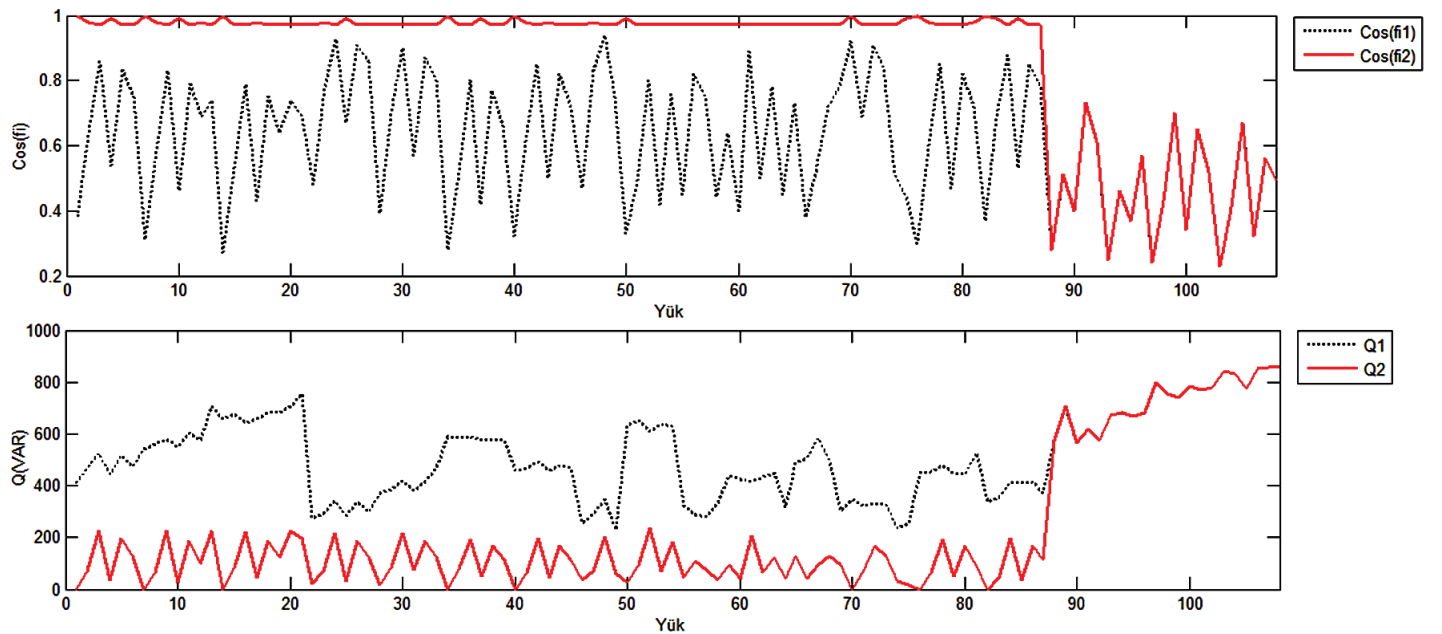

Figure 18 System power factor and $Q$ values, before compensation and after compensation with synchronous motor
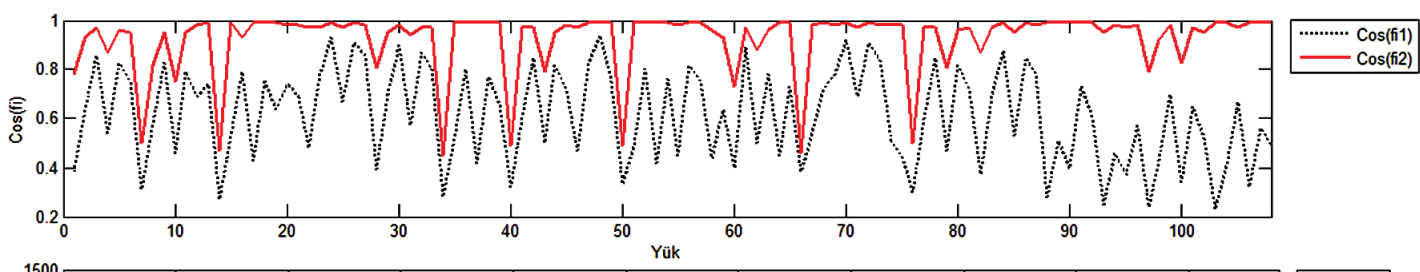

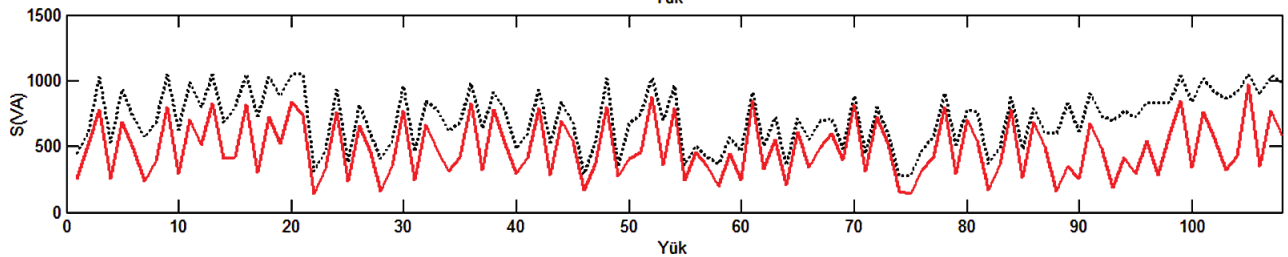

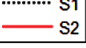

Figure 19 System power factor and $S$ values before compensation and after compensation with capacitor
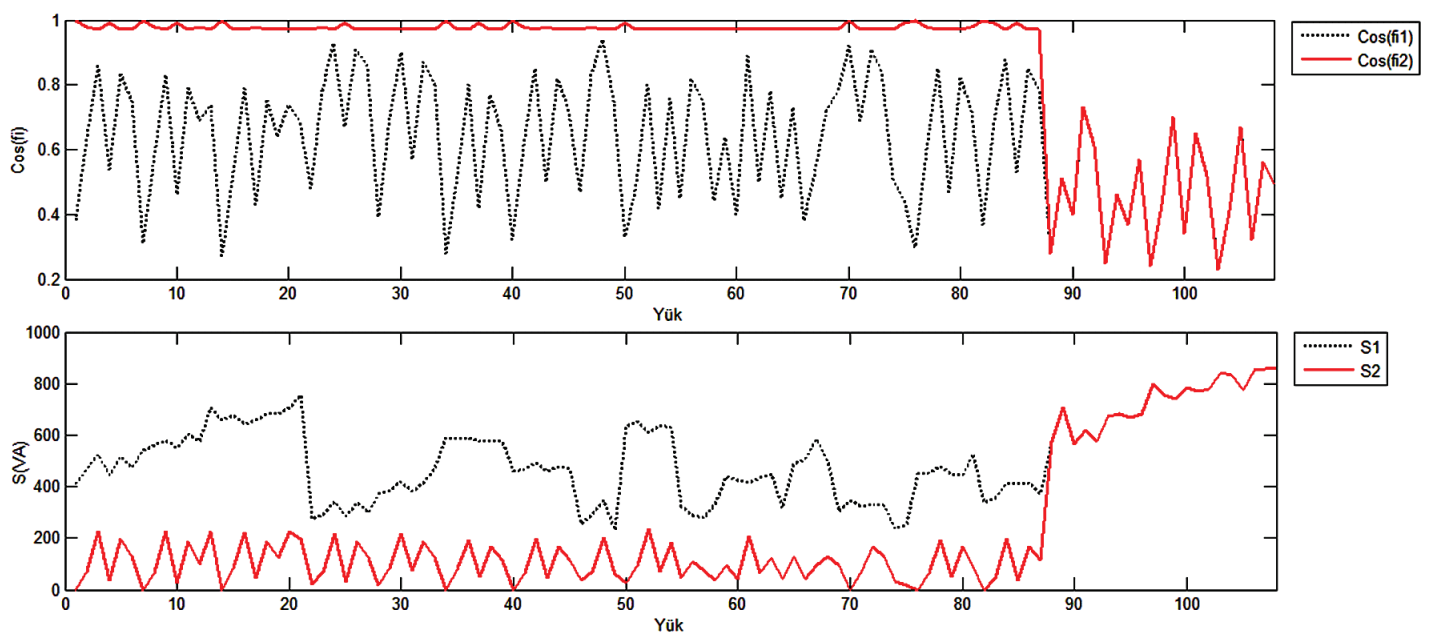

Figure 20 System power factor and $S$ values before compensation and after compensation with synchronous motor
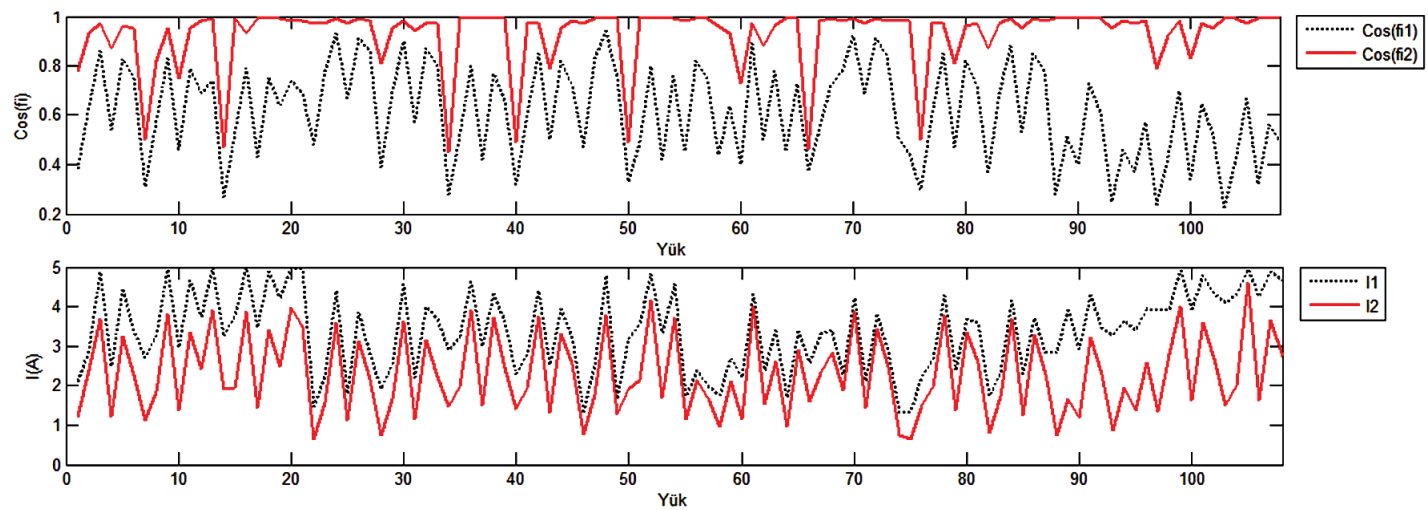

Figure 21System power factor and current values before compensation and after compensation with capacitor 

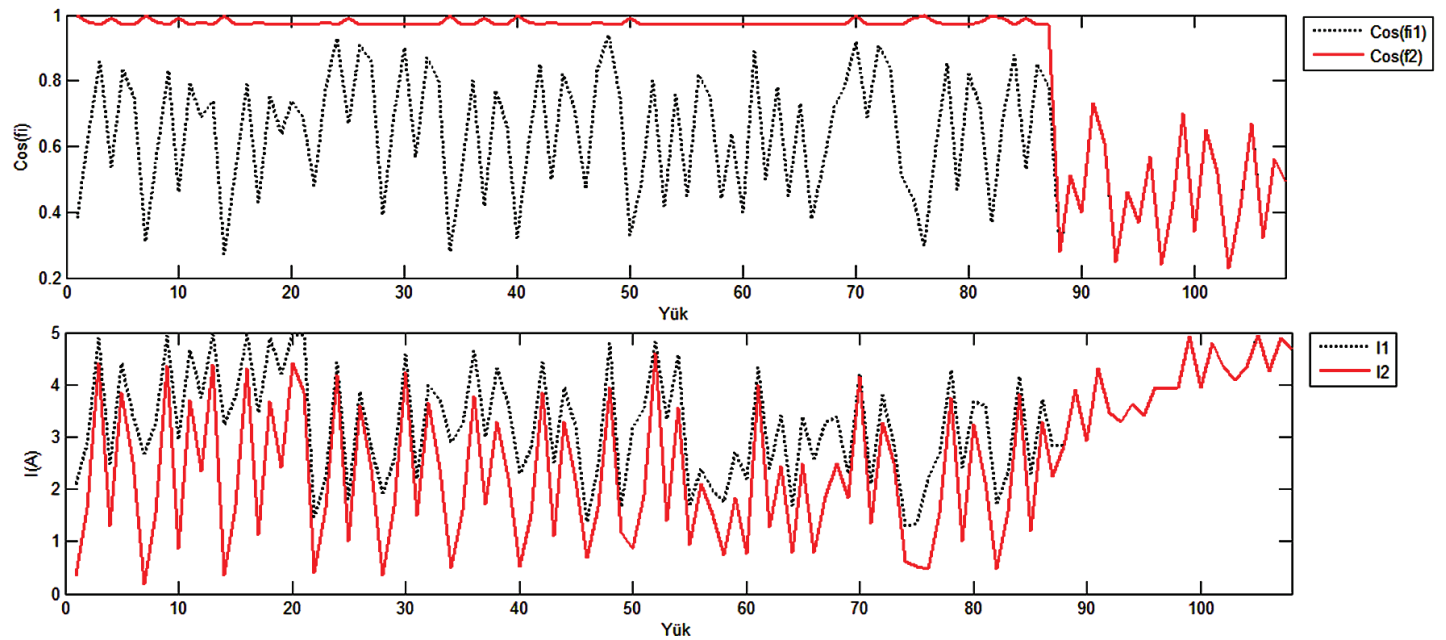

Figure 22 System power factor and current levels pre-compensation and after compensation with synchronous motor
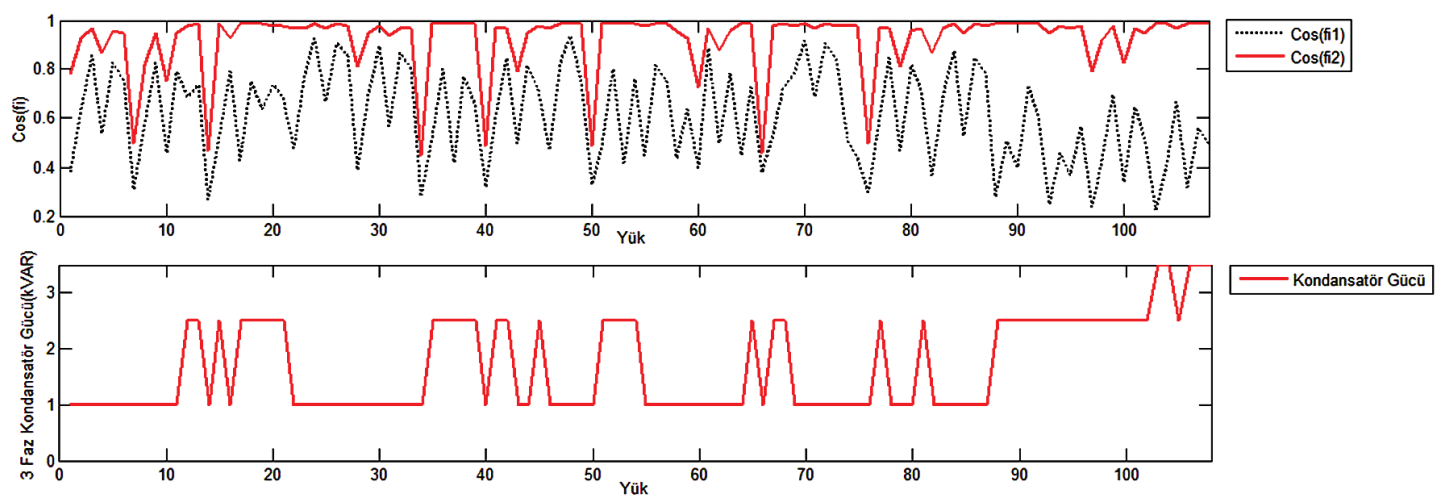

Figure 23 The system power factor and 3-phase power capacitor values used, before compensation and after the compensation with capacitor
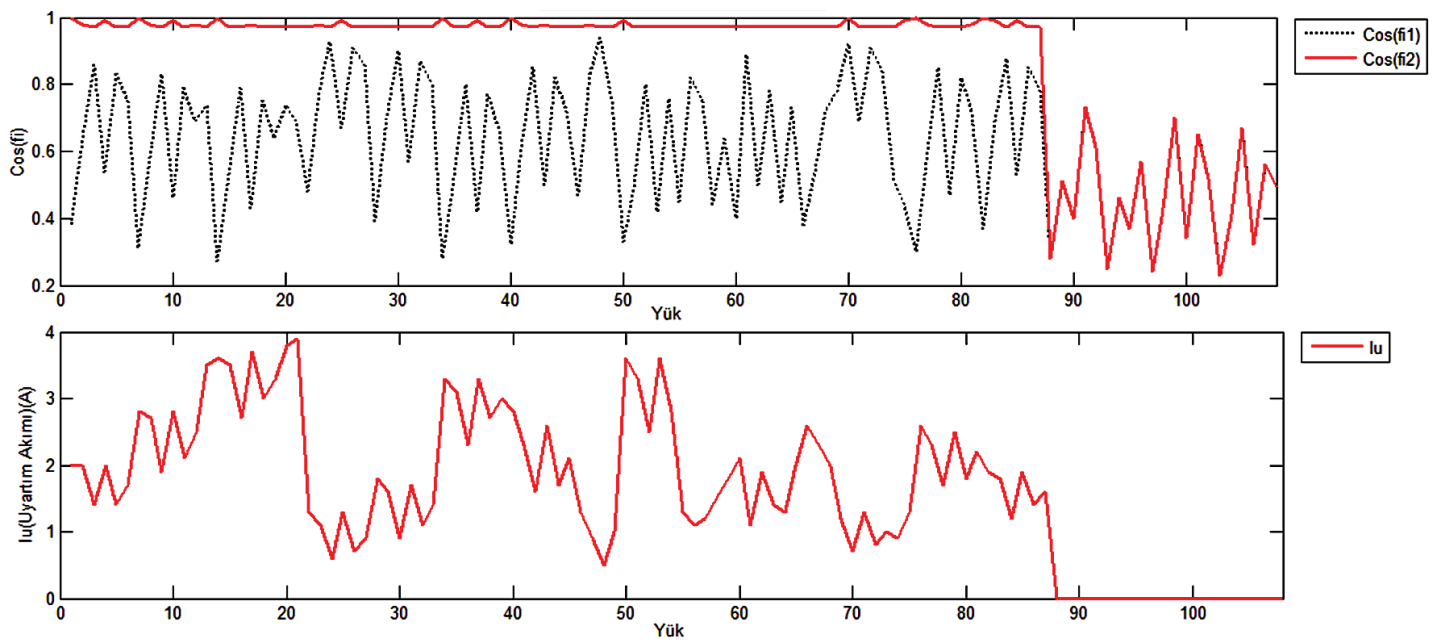

Figure 24 The system power factor and $I_{\mathrm{u}}$ (excitation current) values, before compensation and after compensation with synchronous motor

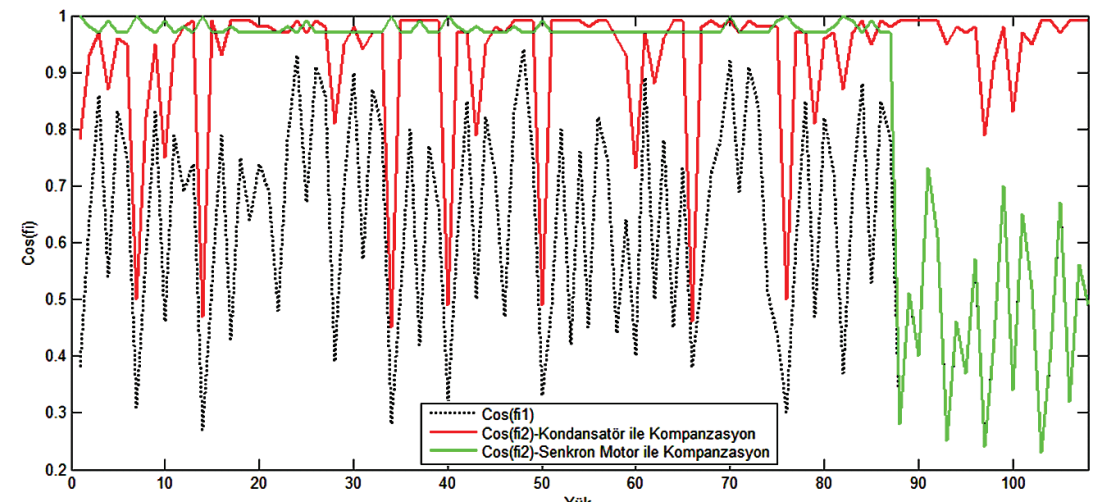

Figure 25 The system power factor value for the pre-compensation and after compensation applications with capacitors and synchronous motors 
In implemented system before the compensation, after capacitor and compensation applications with synchronous motor, new power factor values are obtained. Additionally, measurements of the system of power factor values $P, Q$, $S, \quad I, \quad I_{\mathrm{u}}$ (excitation current) and the third phase compensation capacitors used in power results are shown in Figs. $15 \div 24$

The system power factor values for the precompensation and after compensation applications with capacitors and synchronous motors are shown in Fig. 25.

Before and after the compensation system application, $P$ value remained constant, $Q$ value decreased. This reduction in the reactive force is caused by the actuator means used in compensation applications. As a result of this, energy is supplied by further withdrawal of reactive power from the network.

\section{Conclusions and recommendations}

In this study, a reactive power compensation system has been designed. In the designed system, firstly the compensation is performed by using the capacitor under the specific load condition, then by using the synchronous motor and the results of both applications are compared.

Looking at the results after compensation, the compensation for the existing system with a synchronous motor has been found to be more advantageous. The system with capacitive compensation can be adjusted depending on the number of power factor stages. As the number of stages increases, a more accurate result is obtained. However, as the number of stages increases, the reaction rate of the system decreases. Since the motor excitation current can be adjusted very precisely to the synchronous motor, the reactive power loss of the existing system has become low. The nominal excitation current of the synchronous motor used is maximum 4 Ampere. For the system in this study, if the capacitor stepping forces are chosen to be smaller, the compensation made by the capacitor will become more advantageous and more convenient than the compensation made with the synchronous motor. Because of the capacitors losses, maintenance and facility costs are less than the synchronous motor.

\section{References}

[1] Kocabaş, E. Reactive power compensation and simulation, Master Thesis, Electrical and Electronics Engineering, Marmara University, İstanbul, 2006.

[2] Demirkol, Ö. Measurement and compensation in unbalanced power system containing harmonics, Master Thesis, Electrical and Electronics Engineering, Sakarya University, Sakarya, 2006.

[3] Zhou, Dao, et al. Reduced cost of reactive power in doubly fed induction generator wind turbine system with optimized grid filter. // IEEE Transactions on Power Electronics. 30, 10(2015), pp. 5581-5590. DOI: 10.1109/TPEL.2014.2374652

[4] Miller, T. J. E. Reactive power control in electric systems. A Viley-Interscience Publication, New York, (1982), pp. 182222.

[5] El-Sadek, M. Z.; Fetih, N. H.; Abdelbar, F. N. Starting of induction motors by static VAR compensators. // Third International Conference on Power Electronics and Variable-Speed Drives, (1988), pp. 444-447.
[6] Al Hamrani, M. M. Reactive power optimization using adaptive excitation control of synchronous motors. Master Thesis, Electrical and Computer Engineering, Oregon State University, 2002.

[7] Jones, L. D.; Blackwell, D. Energy Saver Power Factor Controller for Synchronous Motors. // IEEE Transactions on Power Apparatus and Systems. PAS-102, 5(1983), pp. 13911394. DOI: 10.1109/TPAS.1983.318091

[8] Al Hamrani, M. M. Reactive Power Optimization Using Adaptive Excitation Control of Synchronous Motors. Master Thesis, Electrical and Computer Engineering, Oregon State University, 2002.

[9] El-Bolok, H. M.; M. Masoud, E.; MahmoudM. M. A microprocessor-based adaptive power factor corrector for nonlinear loads. // IEEE Transactions on Industrial Electronics. 37, 1(1990), pp. 77-81. DOI: 10.1109/41.45846

[10] Schaefer, R. C. Excitation Control of the Synchronous Motor. // Industry Applications. IEEE Transactions. 35, 3(1999), pp. 694-702. DOI: 10.1109/28.767025

[11] Józsa, L.; Petrovic, I.; Angebrandt, V.; Analysis of possibilities of using series compensation for consequences elimination of driving long transmission lines. // Technical Gazette. 17, 4(2010), pp. 529-535.

[12] Stojkov, M.; Atic, M.; Softic, A. Application of fuzzy logic for reactive power compensation by synchronous motors with variable load. // Technical Gazette. 19, 4(2012), pp. 753-758.

\section{Authors' addresses}

Ercan Nurcan Yilmaz, Assoc. Prof. Dr.

Department of Electrical \& Electronic Engineering,

Faculty of Technology, Gazi University,

06500, Teknikokullar, Ankara/Turkey

E-mail: enyilmaz@gazi.edu.tr

Olcay Aydin, Lecturer

Department of Control and Automation Technologies, Turgutlu Vocational School, Celal Bayar University,

Turgutlu/Manisa/Turkey

E-mail: olcay.aydin@cbu.edu.tr 